\title{
MEDIA SOSIAL SEBAGAI PENDUKUNG JARINGAN KOMUNIKASI POLITIK
}

\author{
Eko Harry Susanto \\ Fakultas Ilmu Komunikasi Universitas Tarumanagara Jakarta, Jl. S.Parman No.1 Jakarta 11440 \\ No. Telp. (021) 56960586 \\ Email : ekos@fikom.untar.ac.id
}

\begin{abstract}
Communication and information technology development makes it easier for interaction between individuals and groups. Message and news traffic are not fully controlled by the state, but are free to flow to public. Therefore, social media that have power to disseminate information, be an option to influence, motivate, and perform actions desired by message spreaders. At the same time, dominance of mainstream mass media is fading away. This study aims to: (1) describe social media users without socioeconomic and political differences, (2) analyze social media and mass media efforts to reach audiences, (3) observe social media as a supporter of political communication networks in democratic state. This study, using qualitative methods, aims to provide a holistic picture of social media in relation to the political communication network utilized by individuals, groups and various political entities. The results of this study are, users of social media are not bound by social, economic and political status; Social media and mainstream mass media have different characters in spreading messages to audiences; And social media is a supporting of political communication network in democracy of the state.
\end{abstract}

Keywords: social media, mainstream mass media, political communication network, state democracy.

\begin{abstract}
Abstrak
Perkembangan teknologi komunikasi dan informasi semakin memudahkan interaksi antar individu maupun kelompok. Lalu lintas pesan dan pemberitaan tidak sepenuhnya dikuasai negara tetapi bebas mengalir pada khalayak. Media sosial yang memiliki kekuatan dalam penyebaran informasi menjadi pilihan untuk mempengaruhi, memotivasi, dan melakukan tindakan yang dikehendaki oleh penyebar pesan. Pada saat yang bersamaan, dominasi media massa arus utama semakin memudar. Penelitian ini bertujuan : (1) menggambarkan pengguna media sosial tanpa perbedaan sosial ekonomi dan politik, (2) menganalisis upaya media sosial dan media massa menjangkau khalayak, (3) menelaah media sosial sebagai pendukung jaringan komunikasi politik dalam demokrasi bernegara. Penelitian ini menggunakan metode kualitatif untuk memberikan gambaran holistik tentang media sosial dalam kaitannya dengan jaringan komunikasi politik yang dimanfaatkan oleh individu, kelompok maupun berbagai entitas politik. Hasil penelitian ini adalah pengguna media sosial tidak terikat oleh status sosial, ekonomi dan politik; media sosial dan media massa arus utama memiliki karakter berbeda dalam menyebarkan pesan kepada khalayak; dan media sosial merupakan pendukung jaringan komunikasi politik dalam demokrasi bernegara.
\end{abstract}

Kata kunci: media sosial, media massa arus utama, jaringan komunikasi politik, demokrasi bernegara

\section{Pendahuluan}

Media sosial berkembang pesat sejalan dengan pertumbuhan dan kemudahan akses informasi yang didukung oleh kekuatan teknologi komunikasi. Media sosial memiliki pengguna aktif sebesar 79 juta. Indonesia merupakan salah satu negara teraktif di media sosial (Global Media
Statistics, 2016). Pola penyebaran pesan yang cenderung bebas memiliki maksud agar segera diketahui publik menjadi tujuan dari para pengguna media sosial, maka tidak menjadi persoalan apakah informasi yang disebarkan itu akurat sesuai prinsip pemberitaan yang baik dan benar. Kecepatan pesan tanpa sumber yang dapat dipercaya 
dan sesuai fakta cenderung berdampak buruk terhadap dinamika kehidupan politik bernegara.

Pew Research Center memaparkan dalam penelitiannya tentang Media Baru di Amerika Serikat bahwasanya konsumsi berita online meningkat tajam. Responden pada tahun 2011-2012 memperoleh berita secara online mencapai $50 \%$, sedikit lebih kecil dari televisi, tapi jauh melebihi surat kabar yang hanya mencapai 29 $\%$ dan radio sekitar 33\%. (Macnamara, 2014:6). Responden mendapatkan berita dan informasi dari media dan jejaring sosial seperti blog, mikroblog (twitter) dan Facebook sejumlah 19\%, sedangkan $8 \%$ lainnya mendengarkan podcast untuk mengakses berita dan informasi.

Media sosial di Indonesia memiliki kecenderungan pemberitaan politik melalui akun individu, kelompok, maupun pihak-pihak yang tidak dapat dipertanggungjawabkan sebagai sumber informasi yang layak. Masyarakat penerima pesan juga tidak menghiraukan tentang keakuratan maupun keabsahan informasi, yang terpenting adalah memenuhi kebutuhan informasi sepihak sesuai dengan kepentingan. Direktorat Reskrimsus Polda Metro Jaya mendeteksi ada ribuan akun media sosial dan media online yang menyebarkan informasi hoax, provokasi, hingga menyangkut Suku Agama Ras dan Antar Golongan (SARA). Sekitar 300 akun telah diblokir dengan motif politik yang bertujuan agar banyak dikunjungi oleh pengguna media sosial. (Kominfo, 2017)

Kehidupan politik di Indonesia rentan terhadap konflik antar kelompok politik yang dikarenakan berlimpahnya pesan, pemberitaan daninformasiyangbermuatansalingmengritik, prasangka berlebihan, subyektivisme, sikap sektarianisme, komunalisme dan semangat sub nasional. Memang tidak semua orang menilai positif tentang media sosial sebagai sumber informasi, karena itu penting untuk mempertimbangkan kritik dan kelemahannya (Cann, Dimitriou and Hooley, 2012 : 11).

Isi pesan media sosial yang tersebar bebas dan mudah diakses, seolah-olah menafikan keberadaan media massa utama sebagai sumber berita faktual yang berlandaskan pada etika pemberitaan. Media sosial dalam lingkup media baru memiliki sifat yang fleksibel. Media baru merupakan media yang menawarkan digitilisasi, konvergensi, interaktif, dan pengembangan jaringan dalam pembuatan pesan dan penyampaian pesan (Flew, 2002: 11-22). Pengguna media baru memiliki kemampuan untuk menawarkan interaktifitas, memiliki pilihan informasi yang dibutuhkan, sekaligus mampu mengendalikan informasi yang dihasilkan sesuai yang diinginkannya. Media baru yang berkembang pesat memiliki salah satu kekuatan yaitu kemampuan menawarkan relasi interaktif.

Penggunaan media sosial yang semakin kuat ini meminggirkan media massa mainstream dalam persaingan penyebaran informasi yang berhubungan dengan politik dan kekuasaan negara. Data Serikat Perusahaan Pers (SPS) menyebutkan, dalam 6 tahun terakhir terjadi penurunan oplah surat kabar nasional secara signifikan. Jumlah oplah pada 2011 masih berkisar 9 juta lebih, namun pada 2016 menyusut 11\% menjadi sekitar 8 juta (Industri 
Bisnis, 2017). Media massa mainstream ataupun media massa konvensional menjadi kehilangan sejumlah khalayak (Merdeka, 2107). Perjalanan media massa dianggap berliku pasca reformasi politik yang mengusung transparansi komunikasi menjadi sirna tergerus oleh eksistensi media sosial yang bebas tetapi mengabaikan aspek kebenaran. Litbang Kompas menunjukkan data selama bulan November 2014 sampai dengan Oktober 2015, percakapan negatif di media sosial dalam kisaran $61 \%$ sedangkan percakapan positif hanya $39 \%$ (Litbang Kompas, 2015).

Reformasi tahun 1998 sebagaimana dalam Undang-Undang Nomor 40 Tahun 1999 tentang Pers merupakan tonggak demokrasi politik, memiliki kepedulian tinggi terhadap peran media massa untuk menjaga keberadaban kehidupan berbangsa dan bernegara. Media massa pasca reformasi politik melepaskan diri dari belenggu ketertutupan dan sensor sehingga membatasi hak untuk memperoleh dan menggunakan informasi. Pola penyebaran pesan tidak lagi sepenuhnya diwarnai oleh ketertundukan dalam jerat regulasi kerahasiaan dan hegemoni politik pemerintah yang berkuasa. Semua keunggulan sebagai pendukung demokrasi politik tersebut seolah kurang bermakna ketika masyarakat lebih mengandalkan media sosial untuk memenuhi kebutuhan informasi.

Masyarakat lebih percaya terhadap media sosial meskipun menyadari bahwa akurasinya tidak terjamin. Dalam situasi persaingan politik antar kelompok yang memanas, masyarakat lebih menyukai pesan media sosial yang bermuatan kritik dan tuduhan negatif terhadap kelompok politik yang tidak sejalan, maka wajar jika semakin keras kritik yang meskipun tidak berdasarkan pada aspek faktual justru menjadi semakin disukai dan berkembang pesat tanpa batasan stratifikasi sosial, ekonomi dan politik.

Kekuatan dan popularitas media sosial, partai politik, institusi politik, kelompokkelompok politik, dan berbagai entitas di masyarakat yang bersentuhan dengan pemerintah dan kekuasaan negara, berupaya memanfaatkan media sosial sebagai pendukung kekuatan untuk mempengaruhi khalayak. Kelompok-kelompok politik ini menggalang opini untuk menyalahkan pihak yang tidak disukai dan secara berkesinambungan mengeksplorasi pesan dalam aroma persaingan. Media sosial dalam jaringan resmi kelompok politik tidak berdiri sendiri dalam mengeksplorasi informasi untuk kepentingan kelompok, sebab muncul sedemikian banyak media sosial dari pendukung dan simpatisan yang menyebarkan berita-berita bohong yang tidak sejalan dengan sikap resmi lembaga ataupun kelompok politik.

Bingkai kontestasi politik yang menyebarkan berita bohong menyebabkan ketidakpastian di masyarakat. Informasi yang sifatnya menghasut, menyebarkan kebencian, dan pesan negatif lain untuk kelompok lawan politiknya berpotensi menimbulkan konflik antar kelompok. Media sosial sebagai media alternatif yang didukung oleh kekuatan teknologi komunikasi, sesungguhnya me- 
miliki banyak manfaat dalam rangka meningkatkan pemahaman terhadap demokratisasi komunikasi menuju masyarakat informasi yang adil sejahtera. Media sosial yang dimanfaatkan untuk hal positif tentu saja mampu membangun jaringan komunikasi politik yang interaktif diantara kelompok politik dengan pasa simpatisan atau massa. Indonesia yang memiliki perkembangan demokrasi secara pesat pasca reformasi politik, membuktikan bahwa media sosial memberikan kontribusi maksimal dalam menciptakan kebebasan berkomunikasi. Media sosial mudah dimanfaatkan oleh setiap individu karena karakternya yang fleksibel pada institusi maupun kelompok, untuk melakukan penyebaran pesan yang tidak sejalan dengan keberadaban dalam berbangsa dan bernegara.

Media massa utama yang diharapkan dapat menyebarkan informasi dengan transparan, masuk dalam perangkap sebagai media partisan yang terselubung maupun terang-terangan mendukung kekuatan politik tertentu. Hal tersebut mengakibatkan masyarakat tidak percaya sepenuhnya terhadap media mainstream atau media arus utama yang memiliki ikatan dengan kelompok ataupun organisasi politik di Indonesia.

Kondisi ini tidak terlepas dari pengalaman masalalu. Penyebaraninformasi diawasai dengan ketat oleh pemerintah yang berkuasa sebagai pihak yang memiliki kekuatan besar dalam mengendalikan media massa untuk kepentingan politik pemerintah. Lembaga ataupun institusi pengelola media massa konvensional dinilai sebagai media yang tidak bebas dari pengaruh politik ataupun pemilik modal yang berkepentingan mencari keuntungan.

Permasalahan pada penelitian ini adalah bagaimana media sosial dengan pengguna yang beragam menjangkau khalayak yang terhubung dalam jaringan komunikasi politik. Konteks penelitian ini berfokus pada media sosial yang dimanfaatkan oleh pengguna untuk mendukung komunikasi politik, dalam meraih, mendukung serta mengkritisi figur, kelompok maupun institusi politik. Tujuan penelitian antara lain; (1) menggambarkan pengguna media sosial tanpa perbedaan sosial ekonomi dan politik, (2) menganalisis upaya media sosial dan media massa arus utama dalam menjangkau khalayak, (3) menelaah media sosial sebagai pendukung jaringan komunikasi politik dalam demokrasi bernegara.

Hasil penelitian terdahulu tentang media sosial dan komunikasi politik yang dilakukan oleh Afdal Makkuraga Putra menjelaskan bahwa dalam pemilihan kepala daerah di Banten tahun 2011, media baru atau situs jejeraing sosial seperti facebook dan twitter dimanfaatkan untuk kepentingan komunikasi politik, tetapi hanya bersifat informasi yang kurang interaktif (Putra, 2011).

Penelitian lain dari dari Julia Caplan, dalam pemilihan anggota Konggres di Amerika Serikat tahun 2012 menunjukkan bahwa para kandidat yang bersaing menggunakan media sosial, terutama twitter untuk menyebarkan informasi. Jejaring sosial sebagai alat untuk menarik pemilih dalam struktur sosial demi memperoleh kemenangan dalam persaingan. Twitter 
yang sangat popular menciptakan peluang bagi para politisi di ranah politik, memiliki guna untuk memotivasi dan mengaktifkan pengikut mereka dan membedakan diri dari pesaingnya (Caplan, 2013)

Teori yang digunakan adalah teori komunikasi politik dan jaringan komunikasi politik dalam perspektif makna yang muncul pada interaksi antar manusia. Teori pendukung penelitian ini mencakup eksistensi media sosial, media massa arus utama atau media tradisional, dan teori demokrasi bernegara.

Media Sosial merupakan jaringan untuk berkomunikasi melalui teks, video, blog, foto, update status di situs Facebook, MySpace, LinkedIn dan lain-lain dalam bentuk percakapan online yang mudah diakses (Alejandro, 2010:1). Sedangkan Schottmuller menyatakan bahwa media sosial esensinya sebagai saluran komunikasi, atau alat yang digunakan untuk menyimpan, mengakumulasikan, berbagi, berdiskusi atau menyampaikan informasi dalam komunitas online (https://www.marketingprofsu. com/ Angie Schottmuller, akses 22 Januari 2017). Media sosial didukung oleh teknologi komunikasi, antara lain dalam bentuk forum internet, weblog, blog sosial, microblogging, wiki, podcast, foto atau gambar, video, dan perangkat lain dalam penggunaan informasi. (Kaplan \& Haenlein, 2010: 62). Media sosial juga memberikan layanan dalam interaksi melalui teknologi dengan media internet disebut interactive media (Burke, 2000: 380).

Media sosial merupakan cara baru dalam berkomunikasi yang lebih interaktif (Karjaluoto, 2008: 2). Eksistensi media sosial yang semakin menguat di masyarakat menjadikan media massa arus utama harus berupaya mengimbangi dengan informasi yang bermutu. Media massa merupakan lembaga sosialisasi pesan formal maupun informal yang penting dalam bermasyarakat (Blake dan Haroldsen, 2009:79). Media massa dalam sistem makro merupakan subsistem di masyarakat yang dapat mengontrol dan membagikan pengetahuan" (Donohue, Tichenor \& Olien, 1973: 652) . Sistem pers adalah sub-sistem dari sistem politik, dan media massa memegang peranan penting di dalam kehidupan politik (McQuail, 2010). Politik disosialisasikan melalui media massa untuk mempengaruhi khalayak, memperoleh dukungan, maupun memperkecil permusuhan dalam suatu sistem politik masyarakat (Castells, 2007: 240). Negara demokratis perlu memiliki media yang bebas dan independen untuk pengembangan demokrasi yang mendorong semua kelompok yang ada di masyarakat dapat berpartisipasi dalam mencapai kesejahteraan dan pembangunan berkelanjutan (Dietz dan Osang, 2010: 8).

Pencapaian tujuan dalam perpektif komunikasi politik yang integratif memerlukan jaringan komunikasi politik yang terpola. Jaringan komunikasi berkembang pesat dan mengalami perubahan karena didukung oleh pengintegrasian komputer dan teknologi komunikasi untuk mendukung proses sosial, budaya dan ekonomi dalam suatu sistem kolektif (Fulk \& DeSanctis, 1999). Jaringan komunikasi menawarkan satu jalan untuk saling bergantung, menciptakan ikatan diantara orang-orang yang 
ada di dalamnya melalui teknologi digital, kecepatan komunikasi dalam membangun pemahaman bersama untuk melakukan tindakan kolektif (Gonzalez dan Wang, 2016:96).

Hernando Gonzales berpendapat bahwa jaringan komunikasi merupakan komunikasi yang melibatkan pemuka-pemuka opini dan pengikut yang saling memiliki hubungan komunikasi pada suatu topik tertentu, terjadi dalam suatu sistem sosial tertentu (Bakti dkk, 2015). Etintas politik memanfaatkan jaringan komunikasi untuk kepentingan komunikasi politik, yang secara sederhana diartikan proses produksi, diseminasi dan persepsi informasi politik untuk mencapai tujuan dan tindakan politik tertentu (Gyori, 2016: 14). Komunikasi politik menjadi alat untuk memastikan bahwa proses persiapan dan pelaksanaan keputusan politik merupakan hasil kerjasama antara komunikator dan komunikan selama berlangsungnya komunikasi politik (Chekunova1, Barabash, Trofimova and Lenko, 2016:4). Komunikasi politik adalah sebuah proses interaktif mengenai transmisi informasi kalangan politisi, media pemberitaan dan publik (Norris, 2000: 163). Komunikasi dalam konteks kekinian mengharuskan untuk memperhatikan keberagaman dan mendengarkan apa yang disuarakan masyarakat dalam pemerintahan yang demokratis, sehingga masyarakat dapat menghindari suara ketidakpastian (Crozier, 2006).

Rush dan Althoff berpendapat komunikasi politik merupakan transmisi informasi yang secara politis dari satu bagian sistem politik kepada sistem politik yang lain, dan antara sistem sosial dan sistem politik merupakan unsur dinamis dari suatu sistem politik (Susanto, 2017:313). Esensial jaringan komunikasi politik merupakan keterkaitan dan hubungan dalam komunikasi yang berisi pesan politik diantara anggotanya yang memiliki tujuan politik.

Prinsip demokrasi dalam penerapan kehidupan bernegara menurut Abraham Lincoln (1809-1865) adalah pemerintah dari rakyat, oleh rakyat, untuk rakyat. Demokrasi adalah sistem pemerintahan dimana kedaulatan politik dipertahankan oleh rakyat, dan dilaksanakan langsung oleh warga yang memiliki hak menentukan siapa yang layak memerintah, ada hukum otoritas pemerintah, dan menjamin kebebasan tertentu bagi setiap warga negara (Campbell, 2008:4). Ddemokrasi merupakan tiga prinsip fundamental, sedangkan penentu dasar demokrasi adalah, persamaan, kebebasan, dan kontrol". (Buhlmann, et.al, 2008: 13). Indeks Persepsi Demokrasi menurut Transparency International Indonesia, mencakup kebebasan sipil yang meliputi kebebasan berpendapat, kebebasan berserikat, kebebasan menjalankan keyakinan, kebebasan diskriminasi. Hak politik terdiri dari hak memilih dan keterlibatan dalam pembuatan kebijakan publik sedangkan kelembagaan demokrasi terdiri dari penyerapan aspirasi masyarakat, efektivitas pengawasan pemerintah, transparansi layanan publik, praktik keadilan hukum, penciptaan pemimpin atau kader (Kompas, 2 Januari 2014: 4). 


\section{Metode Penelitian}

Metode yang digunakan dalam penelitian ini adalah kualitatif, berkaitan dengan upaya mengembangkan fenomena sosial yang bertujuan untuk memahami perilaku dan situasi sosial sekelilingnya, fokus pertanyaan pada mengapa orang berperilaku dan berbudaya seperti yang mereka lakukan, bagaimana pendapat dan sikap terbentuk, bagaimana orang memahami peristiwa yang ada disekitarnya, (Hancock.,et.al, 2009:7). Penelitian kualitatif menggunakan tiga sumber utama: analisis dokumen, wawancara, dan berbagai publikasi dalam bentuk teks maupun online. Sejalan dengan pendapat Potter bahwa dokumen penelitian kualitatif meliputi bahan-bahan seperti surat, memo, catatan, buku harian, artikel, buku, naskah, e-mail, diskusi online, dan sebagainya (Kim, 2016: 45). Penelitian kualitatif bersifat subyektif tergantung dari pengalaman peneliti dan yang diteliti, dalam mengeksplorasi peristiwaperistiwa selama berlangsung penelitian, atau memotongnya jika tidak sesuai dengan masalah yang diteliti (Greenhalgh and Taylor. 1997: 2)

Penelitian ini menitikberatkan pada penelusuran dokumen maupun data online yang terkait dengan eksistensi media sosial dan jaringan komunikasi politik. Media sosial dalam konteks ini menyangkut semua jaringan untuk berkomunikasi yang memanfaatkan internet, dipilih secara purposif dan tidak terbatas pada lokasi penggunaannya, sebab diutamakan memiliki keterkaitan dengan pemakaian media sosial untuk kepentingan politik. Esensinya mencermati berbagai pustaka, dokumen cetak maupun online yang jumlahnya sangat banyak dan dipilih secara sengaja yang memiliki kaitan dengan topik penelitian.

Teknik analisis data yang dipakai menggunakan tiga alur kegiatan yaitu reduksi data, penyajian data, dan penarikan kesimpulan (Miles \& Huberman, 2009:19). Inti dari analisis data kualitatif terletak pada proses mengkaitkan pernyataan yang menggambarkan fenomena, mengklasifikasikannya, dan melihat konsepkonsep terkoneksi secara komprehensif sebagai hasil penelitian ilmiah (Dey, 1993: 31). Pendapat lain menyatakan analisis data penelitian kualitatif berdasarkan pada dokumen, transkrip wawancara, keterkaitan antar teks ataupun catatan, kutipan menarik tertentu, dan catataan lapangan dipakai untuk menyajikan data secara menyeluruh. Hal yang tidak berhubungan dengan topik penelitian harus dihilangkan untuk menjaga keutuhan hasil penelitian. (Greenhalgh \& Taylor. 1997: 4)

\section{Hasil Penelitian dan Pembahasan}

Hasil penelitian ini diulas dalam tiga subpembahasan temuan yang diperoleh dalam penelusuran, penelaahan serta pengkajian informasi yang berhubungan dengan topik penelitian. Temuan pertama menyangkut fleksibilitas pemanfaatan media sosial. Temuan kedua tentag teknologi komunikasi merupakan kekuatan dari media sosial untuk berkembang pesat. Temuan ketiga tentang adanya perbedaan perilaku pengguna media sosial dalam stratifikasi politik yang terdapat di masyarakat. 
Fleksibilitas Pemanfaatan Media Sosial dalam Interaksi dan Komunikasi

Keluwesan media sosial berhubungan dengan pemanfaatan penggunaan yang semakin mudah. Setiap orang tanpa kesulitan dapat menggunakan media sosial untuk mencari, memperoleh dan memanfaatan informasi yang beragam dalam koridor kebebasan berkomunikasi. Media sosial sebagai entitas pengolah dan penyebar informasi yang fleksibel dimanfaatkan oleh pengguna yang tidak tersegmentasi dalam kelompok sosial, ekonomi dan politik. Fleksibilitas media sosial mampu membangun dan meningkatkan hubungan antar individu maupun kelompok di dunia maya, yang tidak dibatasi oleh perbedaan status di masyarakat.

Bentuk popular media sosial berbasis internet antara lain, adalah Blog, Twitter, Facebook, Wikipedia, dan MySpace. Media sosial berkembang seiring meningkatnya aplikasi berbasis internet yang bersifat dua arah (Web 2.0) sehingga pengguna mudah berpartisipasi, berbagi, dan menciptakan isi untuk membangun kesamaan makna.

\section{Asosiasi Penyelenggara Jaringan} Internet Indonesia (APJII) pada tahun 2016 memiliki data survey bahwa terdapat 132,7 juta orang Indonesia telah terhubung ke internet, naik 51,8 persen dibandingkan jumlah pengguna internet pada 2014 yang hanya 88 juta pengguna internet. (Kompas, 2016)

Media sosial memiliki hakikat untuk memberikan keleluasaan bagi pengguna untuk berinteraksi lebih intensif tanpa jarak dan waktu yang seringkali menjadi penghambat. Pesan dapat mengalir dengan cepat kepada pihak yang berkepentingan ataupun entitas yang memiliki perhatian terhadap berbagai pemberitaan. Sosial media memang mempermudah para penggunanya untuk berbagi dan menciptakan pesan melalui jejaring sosial, media online, forum dunia maya dan dunia virtual (Mayfield, 2008: 6).

Media sosial yang termasuk media baru memiliki kesamaan saluran tertentu yang dibedakan berdasarkan jenis, kegunaan, konten dan konteks (Rice, dalam Mc.Quail, 2010: 143). Lima macam media baru tersebut adalah (1) Media komunikasi interpersonal, mencakup telepon dan email, yang secara umum kontennya bersifat pribadi, mudah hilang dan hubungan yang tercipta lebih penting dibandingkan informasi yang disampaikan, (2) Media interaktif, yang didasarkan pada komputer dan video game memiliki kekuatan pada interaktivitas dan dominasi proses (3) Media pencari informasi, misalnya internet, yang dipandang sbg perpustakaan dan sumber data, yang aktual dan mudah diakses, (4) Collective participatory media, meliputi penggunaan internet untuk tujuan berbagai dan menukar informasi, ide, pengalaman dan pembangunan hubungan personal, (5) Substitution of Broadcast media, merupakan referensi utama dalam menggunakan media untuk menerima atau mengunduh konten yang telah disiarkan atau didistribusikan oleh media lain sebagaimana program televisi yang telah disiarkan.

Berdasarkan Pew Research tahun 2015, pengguna media sosial memiliki 
keberagaman dari aspek umur, jenis kelamin, stutus sosial ekonomi, tingkat pendidikan, ras, etnisitas, penduduk desa dan perkotaan (Perrin, 2015 : 3). Keberagaman pengguna media sosial yang memiliki kesamaan dalam mencari informasi merupakan sasaran penyebaran informasi para integrator sosial yang berupaya membangun konten homogen sesuai dengan kepentingannya. Pada konteks ini, meskipun mempunyai kesempatan untuk mengemukakan pendapat, tetapi para pengguna dalam posisi pasif sebagai penerima informasi, sehingga pembuat pesan leluasa untuk terus menerus memproduksi pesan untuk mendapatkan keuntungan.

Keleluasaan para pembuat pesan yang positif maupun negatif semakin kuat karena perangkat untuk mengakses atau menggunakan media sosial semakin murah dan terjangkau oleh masyarakat meskipun dalam kualitas yang terbatas. Data dari APJII tahun 2016 menerangkan bahwa rata-rata pengakses internet di Indonesia menggunakan perangkat genggam. Rinciannya adalah 67,2 juta orang atau 50,7 persen mengakses melalui perangkat genggam dan computer, 63,1 juta orang atau 47,6 persen mengakses dari smartphone, sedangkan 2,2 juta orang atau 1,7 persen mengakses hanya dari komputer. Melihat pengakses internet menggunakan perangkat genggam, sudah barang tentu terkait pula dengan pengguanaan media sosial. Media sosial memiliki fungsi antara lain untuk memperluas interaksi sosial manusia menggunakan internet dan teknologi web, mentransformasikan praktik komunikasi searah media siaran dari satu institusi media ke banyak audience (one to many) menjadi praktik komunikasi dialogis antar banyak audience (many to many). Media sosial mendukung demokratisasipengetahuan dan informasi yang dibutuhkan masyarakat. Perkembangan dalam diseminasi informasi yang sangat progresif dalam lingkup kebebasan komunikasi antara lain mentransformasi seseorang sebagai pengguna isi pesan, menjadi pembuat pesan itu sendiri. Media sosial sebagai media penyebaran pesan sebagai jurnalisme warga, membutuhkan penyesuaian standar jurnalistik agar produk yang dihasilkan sesuai dengan kaidah dasar jurnalisme. "Jurnalisme warga perlu perlindungan, karena menjangkau halhal yang bersifat sangat lokal yang jarang bisa disentuh oleh jurnalisme arus utama," kata Eni Mulia, Direktur Eksekutif Perhimpunan Pengembangan Media Nusantara (Kompas, 30 Maret 2017, halaman 12).

Pengguna media sosial yang beragam dan berasal dari tingkat sosial, ekonomi dan politik yang berbeda, diikat oleh satu kebiasaan dan perilaku yang berhubungan dengan kultur literasi malas membaca dan mencari kebenaran. Situs Berita Satu mengungkapkan, kondisi masyarakat Indonesia pada umumnya tidak lekat dengan budaya membaca dan menulis, ingin yang serbainstan, serta daya kritis masih rendah. Gejala ini tidak hanya dimiliki oleh mereka yang berpendidikan rendah, kelas menengah dengan pendidikan tinggi pun banyak yang seolah kehilangan akal sehat manakala menerima materi informasi yang tidak akurat. Informasi itu diamini hanya karena sesuai dengan sentimen pribadi atau kelompoknya tanpa pikir panjang tentang 
apakah benar, apakah membahayakan, apakah memecah belah atau tidak, informasi kemudian dibagikan kepada yang lain (Berita Satu, 2017)

Keberagaman pengguna ini diikat oleh suatu kepentingan yang merujuk kepada ketidaksukaan atau kecintaan terhadap suatu entitas yang mereka percaya dapat memberikan hal yang lebih baik. Gerakan sosial politik dunia maya kemungkinan ada yang diikat oleh kepentingan politik dalam memburu kekuasaan dan tujuan bisnis di level elite atau masyarakat tingkat atas. Di sisi lain dalam posisi sebagai massa pada umumnya, bukan mustahil mereka diikat oleh nilai-nilai sektarian, semangat sub-nasional, komunalisme dan semangat permurnian kepercayaan yang menguat, tentu ada juga ikatan lain yang muncul dalam penggunaan media sosial adalah kepentingan-kepentingan lain yang merujuk kepada perasaan senasib sebagai warga yang kurang beruntung, mereka yang terpinggirkan oleh sistem sosial ekonomi dan politik yang dibangun oleh kekuasaan. Kelompok pengguna bahkan ada yang sama sekali tidak menghiraukan etika kehidupan bernegara karena perilaku hedonisme yang menggejala.

Pengguna media sosial yang heterogin dari aspek sosial budaya, ekonomi dan politik itu, tidak dapat disangkal bahwa mereka dapat bertindak sebagai pribadi ataupun kelompok yang memanfaatkan media sosial untuk kepentingannya yang beragam dan berhubungan dengan opini publik demi memenuhi kebutuhan informasi menyenangkan meski tidak benar dan menyesatkan. Majalah Tempo mengemukakan kecenderungan hoax adalah berita buruk, orang ramai diharapkan tidak sesuka hati menyebarkan berita tidak sahih. Kenyataannya, tanpa pemeriksaan yang cermat, sebagian orang turut menikmati berita bohong karena isi kabar tersebut memenuhi harapannya tentang keadaan orang atau lembaga yang menjadi korban hoax (Sahidah, Tempo 2017:62)

Penggunaan media sosial dalam struktur politik yang melekat pada elite cenderung untuk memenuhi kesenangan semata terhadap informasi tentang lawan politiknya, melampiaskan dendam politik, membangun konflik, meminimalisir konflik, mencari dukungan massa untuk meraih atau mempertahankan jabatan publik, pencitraan, dan perilaku lain yang bermuara kepada kepentingan politik. Informasi dan pesan yang disebarkan tersebut sebagai respon terhadap pemberitaan positif maupun negatif, bisa tidak sesuai kenyataan, penuh rekayasa ataupun tidak dapat dipertanggungjawabkan kebenarannya.

Media sosial pada level massa sebagai basis suara kelompok politik, dipakai sebagai alat untuk mencari informasi yang dapat memenuhi kebutuhan yang bersifat positif, seperti memberikan pembelajaran, pemahaman luas terhadap kehidupan bernegara dan menyuarakan harapan untuk kehidupan yang lebih baik. Media sosial memiliki sisi lain yang dipakai untuk mencari informasi yang bersifat negatif terhadap individu maupun kelompok yang tidak disukai, misalnya pesan yang memanaskan pertikaian antar kelompok, 
kebencian terhadap mereka yang tidak disukai, mengunggulkan kelompoknya dan bersifat etnosentrisme, sektarianisme, komunalisme, semangat sub- nasional dan pesan atau berita negatif lainnya yang memberikan kepuasan dalam jerat konflik yang laten maupun manifes.

Dalam pemberitaan di Surat Kabar Pikiran Rakyat, tampak perbedaan penggunaan media sosial oleh elite, pada konteks ini Bupati Kabupaten Karawang dan masyarakat pada umumnya. Dalam pemberitaan itu, pada intinya, banyaknya keluhan tentang jalan rusak disampaikan masyarakat melalui media sosial, dan Bupati Karawang Cellica Nurrachadiana, juga menanggapinya melalui media sosial. Namun, alih-alih mendapat simpati, jawaban bupati itu malah mengundang kritikan beragam dari masyarakat karena mengemukakan berbagai dalih pembelaan melalui akun facebooknya (Pikiran Rakyat, 2017)

Secara esensial, media sosial yang fleksibel untuk berkomunikasi dan berinteraksi di dunia maya, dimanfaatkan oleh pengguna yang tidak terikat oleh status sosial ekonomi dan politik. Pengguna media sosial pada umumnya memiliki perilaku yang sama dalam kultur malas mencari kebenaran.

\section{Perbedaan Stratifikasi Politik dalam Peng- gunaan Media Sosial}

Perkembangan teknologi komunikasi memiliki implikasi mencerdaskan, memperluas wawasan, tetapi sekaligus berpotensi merusak nilai sosial ekonomi dan politik yang sudah melembaga. Salah satu perwujudan dari teknologi komunikasi adalah media sosial yang semakin mudah digunakan untuk berinteraksi dan menyebarkan informasi. Media sosial yang berkaitan dengan digitalisasi informasi menjadi kekuatan untuk menjangkau khalayak maupun pengguna. Pasar digital Indonesia pada 2014 mencapai US\$ 12 miliar, meningkat US\$ 8 miliar dibandingkan 2013. Diprediksi pada tahun 2020, Indonesia bakal menjadi pasar digital terbesar di Asia Tenggara (http://www. indotelko.com/?c=in\&it, akses 27 Oktober 2015).

Media sosial sering dihubungan dengan kebebasan demokrasi informasi karena mengubah seseorang dari pembaca konten, menjadi penerbit konten. Ini merupakan pergeseran dari mekanisme siaran, berakar pada percakapan antara penulis, orang, dan teman sebaya. Unsur fundamental media sosial adalah pertama, media sosial melibatkan saluran sosial yang berbeda dan online menjadi saluran utama. Kedua, media sosial berubah dari waktu ke waktu, artinya media sosial terus berkembang. Ketiga, media sosial bersifat partisipatif. "penonton/ khalayak" mempunyai hak bicara dianggap kreatif, sehingga dapat memberikan komentar (Evans, 2008: 34)

Keterlibatan pengguna yang merangkap sebagai sebagai khalayak, merupakan fleksibilitas dalam dalam penyebaran pesan. Secara umum media sosial dapat menghilangkan batas privasi, karena budaya pengungkapan pribadi yang aktif tanpa seleksi kebenaran, etika dan nilai-nilai sosial yang ada di masyarakat. Seringkali terjadi penyalahgunaan data yang diungkapkan 
melalui ruang publik membawa implikasi buruk terhadap hubungan antar manusia dan lingkungannya. Kecenderungan mengungkapkan informasi yang sepele dalam pesan singkat sebagaimana melakukan update status, merupakan kedangkalan yang menjadikan, "media sosial hanya cocok untuk hiburan daripada pekerjaan yang profesional" (Andrew, 2007).

Media sosial dalam perspektif etika pengelolaan pesan, seperti kehilangan kewibawaan karena pengguna yang sesukanya dalam memanfaatkan sebagai media penyebaran pesan. Setiap orang dapat mempublikasikan apapun yang mereka inginkan sehingga sulit untuk mengidentifikasi sejauh mana kontribusi berharga atau memiliki otoritas sebagai sumber informasi yang layak. Media tradisional atau media massa yang memiliki filter ketat untuk menjaga kualitas pesan, memiliki etika dan norma yang sangat ketat dalam urusan penyebaran informasi. Kecermatan dan ketelitian serta sederet aturan tersebut yang memposisikan media massa sebagai media tradisional. Keunggulan yang dmiliki bersifat elitis, namun media massa dinilai oleh kelompok progresif dalam pemberitaan sudah ketinggalan, dan masuk dalam perangkap birokrasi institusi media yang terikat oleh jam kerja, batas penayangan pemberitaan dan sederet aturan lain yang menghambat kecepatan diseminasi pesan kepada khalayak. Berlainan dengan, "media sosial yang menghilangkan keseimbangan kerja, dan memiliki potensi untuk memperpanjang hari kerja dan dan aspek-aspek lain kehidupan" (Carr, 2010 :11).
Media sosial disebut pula sebagai media baru karena memiliki karakter interaktif, dan berbeda dari media utama, sedangkan media utama dikategorikan sebagai media lama. Media utamajuga didukung pula oleh kekuatan teknologi komunikasi. Media lama tetap memiliki khalayak dan sebagai rujukan yang dapat dipertanggungjawabkan. Kategorisasi media lama dan media baru bukan karena media lama yang konvensional penuh dengan etika dan peraturan itu menghilang, tetapi ada media baru, yaitu media sosial yang membawa perubahan dalam penyebaran pesan kepada khalayak.

Media baru menawarkan digitilasasi, konvergensi, interaksi dan pembuatan jaringan kerja dalam pembuatan pesan. Kemampuannya menawarkan hubungan interaktif, memungkinkan pengguna media baru memiliki pilihan informasi apa yang dikonsumsi, sekaligus mengendalikan keluaran informasi yang dihasilkan serta melakukan pilihan-pilihan yang diinginkannya. "Kemampuan menawarkan suatu hubungan interaktif inilah yang merupakan konsep sentral dari pemahaman tentang new media (Flew, 2002: 11-22).

Media sosial mempunyai kekuatan dalam mempengaruhi pendapat masyarakat. Upaya pengagalangan untuk memperoleh dukungan yang cepat menjadi kekuatan media sosial dalam kecepatan penyampaian pesan. Media utama berusah untuk membangun ruang pemberitaan (newsroom) yangadaptifterhadap perkembangan teknologi komunikasi. News room merupakan ruang berita, semua jurnalis dan pekerja media bekerja mengumpulan berita yang akan dipublikasikan melalui di media cetak, atau audio visual. 
Surat Kabar Kompas menuliskan Newsroom Baru Hadapi Media Sosial. Untuk mengimbangi kekuatan media sosial, digunakan Model Data-Driven Journalism menyajikan paket berita multi media secara cepat, efisien, dan murah. Newsroom konvergen untuk mendukung industri pemberitaan. Perpaduan media dengan teknologi multi media. Berbagai informasi dalam bentuk teks, audio, dan visual dapat dipertukarkan untuk penyiaran media cetak, elektronik (audio dan video), serta online. Seorang jurnalis dapat menggunakan sumber dari situs web yang gratis di internet misalnya google, dan memanfaatkan media sosial seperti facebook, twitter dan youtube (Lau Joon Nie, Asisten Direktur Newsplex Asia).

Dic Costolo, CEO twitter menyatakan Indonesia sangat vital bagi twitter. Akhir tahun 2013 meraih keuntungan sebesar 20,5 triliun rupiah, kuartal kedua tahun 2014 pendapatan total twitter sebesar US\$ 312 juta dolar Amerika Serikat. Dari jumlah tersebut, sebagian besar dari pemasukan iklan. Situs microblogging itu diakses sekitar 270 juta pengguna aktif, dengan 500 juta cuitan tiap hari (Majalah Tempo, 26 Oktober 2014).

Secara umum media sosial memiliki pemasukan dari iklan sangat memadai karena para pemilik usaha mengetahui bahwa pengguna ataupun khalayak media sosial sangat banyak, sehingga produk yang diiklankan juga dengan cepat dikenal masyarakat luas. Dalam perspektif pemberitaan yang ideal, media sosial seringkali mengabaikan kebenaran faktual, empati dan keseimbangan, sumber yang tidak jelas, dan berbagai nilai pemberitaan lain yang tidak layak dikonsumsi publik.

Khalayak pada media utama semakin berkurang jumlahnya. Media massa mainstream, memiliki posisi kuat dalam menumbuhkan wawasan khalayak. Surat kabar, majalah, radio, dan televisi memberikan informasi bermutu kepada masyarakat. "Media yang dipakai penguasa sebagai instrumen politik pemerintah untuk menyebarkan dan mempromosikan program sosial ekonomi pemerintah sebagai tujuan nasional" (Biagi, 2005: 350). Keterlibatan pemerintah seringkali lebih banyak memposisikan pers sebagai media yang harus dikontrol.

Kontrol terang-terangan maupun terselubung terhadap media massa bertujuan menjaga keamanan dan stabilitas politik. Media wajib melaksanakan tugas pembangunan dan pemerintah campur tangan dalam membatasi pengoperasian media melalui aneka macam regulasi. Kecenderungan negara menguasai rakyat melalui penyebaran informasi, diulas oleh Durkheim, yang menyebutkan, "negara sering mempunyai gagasan baru untuk mengarahkan masyarakat sejauh mungkin" (dalam Giddens, 1986 :126). Dalam bingkai kebebasan komunikasi, media arus utama terperangkap dalam kontrol pemilik media demi kepentingan politik. Penyebaran informasi merupakan langkah politis untuk mengendalaikan hak masyarakat untuk memperoleh informasi realistis dan akurat dari sumber yang kredibilitasnya diakui (McQuail, 1991:109). Media massa memiliki 
fungsi sebagai arus utama, mestinya independen dan mampu menggambarkan realitas sosial yang terjadi di masyarakat. "Pers harus menghormati hak asasi setiap orang, karena itu, pers dituntut profesional dan terbuka" (Sukardi, 2008: 109).

Permasalahan mengenai pers yaitu pers bebas yang memicu konflik antara media massa dengan masyarakat yang disebabkan oleh pemberitaan yang memihak. Posisi media seharusnya bersikap "konsisten dalam peliputannya, yaitu impartial, fair, balance dan tetap menjadi pelindung masyarakat yang terpingirkan oleh sistem yang menekan dunia saat ini" (Eisy, 2007: 46).

Perkembangan teknologi komunikasi dan demokratisasi informasi, memberikan hak masyarakat untuk memilih sumber informasi yang dapat memenuhi kebutuhan secara cepat. Pilihan menggunakan media social dan meninggalkan media arus utama merupakan hak masyarakat. Media sosial mewartakan gambaran faktual dengan prinsip keseimbangan dan kejujuran, bukan sebatas mengejar kecepatan dalam pemberitaan dan menyebarkan berita bohong demi mempengaruhi kelompokkelompok di masyarakat.

\section{Perbedaan Stratifikasi Politik dalam Peng- gunaan Media Sosial}

Media sosial yang memiliki kekuatan dalam penyebaran informasi politik menjadi pertimbangan bagi elite dalam kekuasaan negara dan partai politik untuk membangun komunikasi politik dengan pendukungnya. "Komunikasi politik merupakan proses interaktif mengenai transmisi informasi kalangan politisi, media berita dan publik (Norris, 1999:163). Pesan dalam komunikasi politik menyangkut; cara kandidat, pemerintah, pelobi, maupun kelompok kepentingan dalam mencapai tujuan strategis, dan mengendalikan opini publik untuk mempengaruhi pengambilan keputusan.

Melalui media sosial, komunikasi politik tidak lagi dominasi linier berjalan satu arah, tetapi bersifat interaktif terbuka di alam maya. Komunikasi virtual ini muncul sebagai gambaran kekuatan media sosial sebagai media baru. Pemanfaatan media baru memungkinkan pengguna dapat membentuk jaringan integratif seluasluasnya, dan dapat menunjukkan identitas berbeda dari pengguna di dunia nyata (Flew, 2002: 25).

Pilihan menggunakan media sosial untuk membangun jaringan komunikasi politik yang kuat merupakan hal yang wajar dalam upaya meraih dukungan. Jaringan komunikasi politik merupakan pola sistematis yang mengatur hubungan antar individu, maupun kelompok dalam pertukaran informasi politik. Terbentuknya jaringan komunikasi politik dengan menggunakan media social merupakan alasan praktis untuk menumbuhkan partisipasi yang mendorong kontribusi dan umpan balik, keterbukaan tanpa jarak antar sumber berita dan khalayak yang dapat menguatkan diskusi (Burke, 2000: 380).

Pemanfaatan media sosial untuk kepentingan politik memiliki tujuan untuk mempertahankan kekuasaan atau sebaliknya memperoleh kekuasaan. Pengguna 
media sosial memiliki perbedaan dalam proses penyebaran informasi politik. Kaum elite bisa saja bertindak sebagai sumber informasi yang faktual, tetapi bisa juga melakukan rekayasa pesan demi memperoleh dukungan. Pada level massa, menggunakan informasi dari media sosial untuk menguatkan identitas kelompok dalam jikatan komunalisme, sektarianisme maupun semangat sub nasional. Transaksi informasi politik ada yang terus berlangsung secara vertikal antara elite dan massa, atau secara horisontal diantara massa maupun antar elite dalam stratifikasi politik masyarakat.

Stratifikasi politik dalam kehidupan bernegara dan masyarakat masing-masing lapisan memiliki perbedaan peran. Enam lapisan stratifikasi politik, yaitu (1) proximate decession maker, (2) influential, (3) aktivis, (4) Attentive Public, (5) Voters, (6) kelompok Nonpartisipan. Setiap lapisan memiliki relasi dan komunikasi politik yang terbuka, sehingga bisa saja tidak ada jarak yang tegas, khususnya yang menyangkut satu lapisan ke atas dan satu lapisan ke bawah (Putnam, 2013:10-14).

Berdasarkan pemaparan Susanto (2013), lapisan pertama, proximate decession maker terdiri dari pejabat partai politik tingkat tinggi dan para anggota legislatif, yang terlibat langsung dalam dan memiliki otoritas membuat kebijakan pemerintahan dan negara. Lapisan kedua, influential, merupakan individu ataupun kelompok yang mempunyai pengaruh kuat dalam politik, dan pendapatnya diperhitungkan oleh pembuat keputusan yerdiri dari para pemilik modal dan birokrat papan atas, banker, pemimpin kelompok kepentingan yang memiliki kekuatan mengontrol politik, dan mereka yang dapat membentuk opini publik.

Lapisan ketiga adalah aktivis, biasanya memiliki pengalaman panjang menghadapi hambatan dan tantangan menjalankan roda organisasi. Mereka yang paling berhak mengisi jabatan-jabatan di partai politik dan memiliki kesempatan pertama menduduki posisi dalam pencalonan anggota legislatif maupun pejabat politik. Kelompok ini adalah warga negara yang aktif dalam kehidupan politik dan pemerintahan. Mereka terdiri dari partai politik, birokrat tinggi menengah, editor surat kabar lokal, dan para penulis.

Kelompok pengamat (attentive public) sebagai kumpulan orang kritis, memiliki banyak informasi, wawasan luas, tapi tidak mau terjun langsung dalam politik. Voters dalam lapisan ini adalah pemberi suara dalam pemilihan umum, memiliki sumber politik kolektif yang penting karena jumlahnya besar, tetapi sebagai individu tidak memiliki pengaruh penting. Kelompok terakhir adalah Nonpartisipan, yang sama sekali tidak berpartisipasi dalam politik karena kemauan sendiri, atau diasingkan oleh penguasa. Mereka memiliki jarak kekuasaan dengan elite politik.

Berdasarkan stratifikasi politik tersebut, penggunaan media sosial di setiap lapisan memiliki perbedaan walaupun secara umum mempunyai kesamaan untuk mendukung tujuan dalam persaingan politik yang laten maupun manifest. Secara rinci stratifikasi politik dan penggunaan media sosial dapat dilihat pada tabel 1 . 
Tabel 1: Stratifikasi Politik dan Penggunaan Media Sosial

\begin{tabular}{|c|c|c|c|}
\hline No & Stratifikasi Politik & Kecenderungan Posisi di Media Sosial & Kepentingan Politik \\
\hline 1 & Proximate decession maker & $\begin{array}{l}\text { Sumber Informasi dan pemasok pesan } \\
\text { politik }\end{array}$ & $\begin{array}{l}\text { Mempertahankan atau } \\
\text { memburu jabatan publik }\end{array}$ \\
\hline 2 & Influential & $\begin{array}{l}\text { Sumber Informasi dan memasok } \\
\text { pesan politik }\end{array}$ & $\begin{array}{l}\text { Memburu jabatan politik, } \\
\text { Memposisikan sebagai elite } \\
\text { pengganti }\end{array}$ \\
\hline 3 & Activist & $\begin{array}{l}\text { Sumber Informasi, pengorganisasi } \\
\text { pesan politik }\end{array}$ & $\begin{array}{l}\text { Memburu jabatan politik, } \\
\text { mengkritisi pesaing politik }\end{array}$ \\
\hline 4 & Attentive Public, & $\begin{array}{l}\text { Penerima Informasi, Sumber } \\
\text { informasi, pengelola informasi, } \\
\text { pengorganisasi pesan }\end{array}$ & $\begin{array}{l}\text { Mengkritisi perilaku politik, } \\
\text { memberikan wawasan politik } \\
\text { ideal }\end{array}$ \\
\hline 5 & Voters & $\begin{array}{l}\text { Penerima Informasi, Meneruskan } \\
\text { informasi }\end{array}$ & $\begin{array}{l}\text { Menguatkan dukungan dalam } \\
\text { persaingan politik }\end{array}$ \\
\hline 6 & Non-participant & $\begin{array}{l}\text { Penerima informasi, Pengabaian } \\
\text { Informasi }\end{array}$ & $\begin{array}{l}\text { Skeptis, apatis, tidak peduli } \\
\text { terhadap informasi politik }\end{array}$ \\
\hline
\end{tabular}

Sumber : Hasil Analisis Data dan Pengamatan

Pada tabel 1 dapat disimpulkan bahwa lapisan pertama sampai ketiga memiliki kecenderungan sebagai pengorganisasi pesan dan membangun opini publik di media sosial. Ketiga kelompok ini juga mempunyai kepentingan untuk memburu jabatan publik maupun jabatan politik. Kelompok ke-empat sampai ke-enam memiliki posisi sebagai penerima informasi dan memberikan umpan balik sebagai bentuk dukungan dan penguatan opini negatif terhadap entitas politik di luar kelompoknya. Kelompok ke-lima dan keenam juga memiliki kesempatan sebagai pemberi informasi tetapi frekuensinya jauh lebih kecil disbanding sebagai penerima informasi maupun meneruskan informasi

Posisi di media sosial dan tujuan politik dalam paradigma komunikasi transaksional maupun interaktif bisa berubah-ubah mengingat pengirim pesan dapat berganti sebagai penerima pesan dalam interaksi di media sosial. Pesan pada media baru dibangun dengan kerjasama khusus antar pihak-pihak yang berkomunikasi. Proses beroperasi pembentukan pesan dilakukan secara horisontal diantara aktor-aktor politik dan juga vertikal ke atas sebagai respon opini publik terhadap mereka yang berwenang (Chekuvanol, et.al., 2013:4). Pemahaman makna terhadap pesan politik dari pengguna media sosial sangat dinamis, sehingga posisi dan tujuan ketika memanfaatkan media sosial bisa dengan cepat berubah.

Dalam upaya membangun kesamaan makna, kelompok pertama sampai ketiga memposisikan penyebaran informasi sebagai alat untuk memperoleh dukungan melalui komunikasi yang integratif. Sejalan dengan Komunikasi dalam perspektif politik, sebagai alat menafsirkan peristiwa, dan membentuk tanggapan masyarakat terhadap kebijakan pemerintah. Keberhasilannya ditentukan oleh cara membingkai pesan yang diterima masyarakat (Győri, 2016 : 14). Berpijak pada pendapat tersebut, jaringan komunikasi politik yang membuka jalan untuk saling bergantung, dan menciptakan ikatan diantara individu dan kelompok dalam satu entitas politik diperlukan membangun pemahaman bersama demi mencapai tujuan politik dalam demokrasi 
bernegara. Prinsip utama demokrasi adalah persamaan, kebebasan, dan kontrol dalam pemerintahan yang berpihak kepada rakyat. Penggunaan media sosial sebagai pendukung komunikasi politik merupakan perwujudan dari kehendak rakyat dalam menggunakan hak politik.

\section{Simpulan}

Pengguna media sosial secara individual, kelompok maupun institusional, dapat bertindak sebagai pengirim maupun penerima pesan dalam komunikasi di dunia maya. Fleksibilitas pemanfaatan media sosial tidak dibatasi oleh status status sosial, ekonomi dan politik yang ada di masyarakat.

Media sosial memiliki kemampuan dalam kecepatan menyampaikan pesan kepada khalayak atau pengguna media sosial lainnya karena dukungan teknologi komunikasi yang mampu menjangkau khalayak lebih luas dan lebih cepat. Keunggulan ini meminggirkan pemberitaan media massa arus utama, yang memerlukan proses panjang dan verifikasi keseimbangan informasi dari sumber pesan yang dipercaya.

Stratifikasi politik yang melekat pada pengguna media sosial berkaitan pula dengan perbedaan dalam menyikapi informasi yang diterima namun memiliki kesamaan dalam mendukung jaringan komunikasi politik untuk mencapai tujuan yang telah ditetapkan.

Saran dalam penelitian ini adalah kemudahan penggunaan media sosial seharusnya sejalan dengan upaya memberikan informasi yang benar, tidak mengabaikan etika dan kebenaran informasi sebelum dipublikasikan atau diteruskan kepada khalayak sebagai pengguna media sosial. Dalam hal keluasan jangkauan, media sosial seharusnya dimanfaatkan untuk membangun jaringan komunikasi politik yang memberikan wawasan politik dalam kehidupan bernegara yang berkeadilan. Ikatan stratifikasi politik yang melekat diantara pengguna media sosial, selayaknya digunakan untuk membangun prinsip keterbukaan komunikasi demi untuk mencapai masyarakat informasi yang demokratis.

Implikasi penelitian media sosial ini adalah, penggunaan media sosial harus mematuhi regulasi pemerintah. Pada konteks ini, dapat dilakukan penelitian lanjutan dengan pendekatan posivistik untuk mengetahui perilaku pengguna media sosial secara obyektif. Dalam aspek hubungan antar manusia dalam penyampaian dan penafsiran pesan, dapat dilakukan penelitian dengan pendekatan kritis, untuk mengeksplorasi konteks dan suasana sosial-budaya, ekonomi dan politik di lingkungan pengguna media sosial.

Implikasi lain adalah upaya menggunakan media sosial untuk membangun jaringan komunikasi politik dengan menyebarkan pesan penguatan kelompok, perlu penelitian lanjutan yang menggunakan pendekatan konstruktivisme untuk mengkaji realitas yang sengaja dibentuk oleh para pengguna media sosial dalam mencari dukungan politik.

\section{Daftar Pustaka}

Alejandro,Jennifer.(2010). Journalism In The Age Of Social Media, University of Oxford, Reuters Institute for the study of Journalism : Hilary and Trinity Terms \& Thomson Reuters Foundation 
Bakti, Iriana, C.C.Priyatna, Evie Novianti dan H.R.Budiana.(2015). "Peran Jejaring Komunikasi Dalam Membangun Kohesivitas Kelompok Tani Tanaman Obat Di Jawa Barat, dalam Edutech, Tahun 14, Vol.1, No.3, Oktober 2015

Berita Satu (2017). Ancaman Disintegrasi, dari http://www.beritasatu.com/blog/ tajuk/5110-ancaman-disintegrasi.html, akses 17 Maret 2017).

Blake, Reed H dan Edwind O. Haroldson. (2009). Taksonomi Konsep Komunikasi, Surabaya : Penerbit Papyrus

Buhlmann, Marc, Wolfgang Merkel, Bernhard Wessels .(2008). The Quality of Democracy. Democracy Barometer for Established Democracies, National Center of Competence in Research: Challenges to Democracy in the 21st Century: Working Paper No. 10a

Burke, Peter (2000). Sejarah Sosial Media, Jakarta : Penerbit Yayasan Obor Indonesia

Campbell, David F. J. (2008). The Basic Concept for the Democracy Ranking of the Quality of Democracy. Vienna: Democracy Ranking.

Cann, Alan, Konstantia Dimitriou, and Tristram Hooley. (2012). Social Media: A Guide for Researchers, University of Leicester : International Centre for Guidance Studies

Caplan, Julia. (2013). Social Media and Politics: Twitter use in Virginia. The Elon Journal of Undergraduate Research in Communications Vol. 4 (1), 5-14

Carr, Nicholas. (2010) The Shallows: What the Internet Is Doing to Our Brains. New York City : W.W. Norton

Castells, Manuel. (2007). Communication, Power and Counter-power in the Network Society, dalam International Journal of Communication 2007 (1), 238-266
Chekuvanol, Marina A, Victor V. Barabash, Galina N. Trofimoval and Galina N. Lenko. (2014). New Media In Political Communication: General Approaches, SHS Web of Conferences. Diperoleh dari https://www.shs-conferences.org / articles/shsconf/abs/ 2016/07/contents/ contents.html

Crozier, Michael. (2006). Rethinking Political Communication as Recursive Governance, Fukuoka Japan : 20th International Political Science Association World Congress

Dietz, Christoph and Helmut Osang .(2010). “German Media Development Cooperation Survey Strong in TrainingWeak in sustainability", dalam Christoph Dietz, Julia Steffenfauseweh, Angelika Mendes (eds.) The „Fourth Estate“ in Democracy Assistance Practices and Challenges of German and International Media Development Cooperation 6th Symposium Forum Media and Development (FoME) 2-3 November, 2010, Wesseling St. Augustin/Berlin: Konrad-Adenauer-Stiftung

Dey, Ian. (1993). Qualitative Data Analysis A User-Friendly Guide For Social Scientists, London and New York : Routledge-Taylor and Francis Group

Donohue, G A, P. J. Tichenor, and C. N. Olien. (1973). " Mass Media Functions, Knowledge and Social Control" dalam Journalism \& Mass Communication Quarterly 50(4):652-659 · December 1973

Evans, Dave, (2008). Social Media Marketing An Hour A Day, Canada : Wiley Publishing, Inc

Eisy, M. Ridlo. (2007). Peranan Media dalam Masyarakat : Kemerdekaan Pers Fondasi Penegakan hak Azasi Manusia, Jakarta : Dewan Pers. 
Flew, Terry. 2002. New Media: An Introduction. New York: Oxford University Press

Fulk, Janet and Gerardine DeSanctis. (1999). “ Shaping Organization Form Communication, Connection, and Community, LA, USA : Sage Publications, Inc

Global Media Statistics.2016. Pengguna Internet di Indonesia, dari https:// id.techinasia.com/talk/statistik pengguna-internet-dan-media-sosialterbaru-di-indonesia, diakses 6 Maret 2017

González-Bailón, S., and Nina Wang .(2016). "The Anatomy Of Protest Campaigns In Social Media", dalam Social Networks (2016), 44: 95-104.

Gyori, Gabor.(2016). The Political Communication of The Refugee Crisis In Central And Eastern Europe, Belgium : Policy Solutions and Budapest Responsible Publisher.

Hancock, Beverley, Elizabeth Ockleford and Kate Windridge.(2009). An Introduction to Qualitative Research, Yorkshire, UK : The National Institute Health Research for Yorkshire and the Humber

Industri Bisnis. (2017, Juli 13). Industri Media Tetap Optimis, dari http://industri. bisnis.com/ read/ 20170713/ 12/671171/ industri-media-bisnis-indonesia-tetapoptimistis, diakses 15 Juli 2017.

Kaplan, Andreas M and Michael Haenlein. (2010). "Users of the world, unite! The challenges and opportunities of Social Media". Business Horizons 53 (1): 59-68.

Keen, Andrew. (2007) The Cult of the Amateur: How the Democratization of the Digital World is Assaulting Our Economy, Our Culture, and Our Values. NYC : Doubleday Currency.
Kim, Hyein Amber. (2016). "Biracial Identity Development: A Case of Black-Korean Biracial Individuals in Korea", dalam International Journal of Multicultural Education. Vol. 18, (3) , 40-56

Kominfo.(2017). Selama 2016,300 Akun Medsos Penyebar Hoax Diblokir Polisi, dari http:// kominfo.go.id/content/detail/8640/selama2016-300-akun-medsos-penyebar -hoaxdiblokir-polisi/0/sorotan_media, diakses 3 April 2017

Kompas. (2013, Desember, 12). Pemanfaatan Jejaring Sosial, Surat Kabar Harian"Kompas", halaman 12

Kompas. (2014, Januari 4). Indeks Persepsi Demokrasi Indonesia, Surat Kabar Harian"Kompas", halaman 15

Kompas. (2017, Maret 30). Standar Kaidah Jurnalistik Tetap Perlu, Surat Kabar Harian "Kompas" halaman 12

Kompas. (2016, Oktober 24). Pengguna Internet di Indonesia Capai 132 Juta, dari http://tekno.kompas.com/ $\mathrm{read} / 2016 / 10 / 24 / 15064727 / 2016$, akses 14 Januari 2017)

Litbang Kompas (2015, Oktober 10). Media Sosial Penggerak Aktif Isu Publik, dari http://nasional.kompas.com/read/ 2015/10/26/ 15010071/ Media. Sosial. Penggerak.Aktif.Isu.Publik?page $=2$, diakses 2 Februari 2017.

Mayfield, Antony Mayfield. (2008). What is Social Media?, an e-book by Antony Mayfield from iCrossing, V 1.4 updated 01.08 .08

Macnamara, Jim. (2014). Media mana yang menentukan pemberitaan? Media massa atau/dan media sosial? Sebuah Laporan Penelitian, iSentia.

Mc.Quail,Denis.(2010).Mass Communication Theory, $6^{\text {th }}$ Edition, London : Sage Publication Ltd 
Merdeka (2017). Mengandalkan Langganan dan Pembaca Tua, dari http://www. merdeka.com/khas/mengandalkanlangganana-dan-pembaca-tua.Htm. diakses 3 Maret 2017

Miles, Matthew B and A. Michael Huberman .(2009). Qualitative Data Analysis, atau Analisis Data Kualitatif, terjemahan Tjetjep Rohendi, Jakarta : Univ. Indonesia Press.

Norris, Pippa. (2000). Political Communications and Democratic Politics, dalam John Bartle and Dylan Griffiths (eds), Political Communication Transformed: From Morrison to Mandelson. Basingstoke: Macmillan

Perrin, Andrew.(2016). Social Media Usage: 2005-2015 65\% of Adults Now Use Social Networking Sites-A Nearly Tenfold Jump In The Past Decade, US : Pew Reseach Center.

Pikiran Rakyat. (2017, April 3). Tanggapan Bupati Karawang di Medsos Soal Jalan Rusak Tuai Kritik, dari http:// www.pikiran-rakyat.com/jawabarat/2017/04/03/tanggapan-bupatikarawang-di-medsos-soal-jalan-rusaktuai-kritik-397923. Diakses 11 April 2017

Putnam, Robert D. (2013). The Comparative Study of Political Elites, Canada: Pearson Education (Electronic Resource)
Putra, Afdal M. (2011).Media Baru dan Fenomena Komunikasi Politik pada Pemilukada di Provinsi Banten 2011. Jurnal UMN Ultima Comm, Volume III (2), 23-34

Sahidah, Ahmad. (2017, April 2). Sekali Lagi Tentang Hoax. Majalah Tempo, halaman 62

Schottmuller,Angie. (2012). Conversion Optimization, SEO, Mobile. Diperoleh dari (https://www.marketingprofsu.com/ instructors/ 17311/angie-schottmuller).

Standar Kaidah Jurnalistik Tetap Perlu (2017, Maret 30). Surat Kabar Harian Kompas, hal 3

Susanto, Eko Harry. (2017).Jokowi's Political Communication in Jakarta Governor Electionto Win Age Based Voters, dalam Mediterranean Journal of Social Sciences Vol 8 (7), Rome Italy : MCSER Publishing, pages $312-321$

Susanto, Eko Harry.(2013, September 5). Caleg Pemilik Modal dan Otoritas Parpol, Harian Media Indonesia, hal.5

Trisha Greenhalgh and Rod Taylor. 1997. How To Read A Paper: Papers That Go Beyond Numbers (Qualitative Research), London, UK : BMJ Publishing Group Ltd

Undang-Undang Republik Indonesia Nomor 40 Tahun 1999 tentang Pers, dalam " Hukum Jurnalistik”, Jakarta : Seri Pustaka Yustisia 